\title{
Protective Sexual Behaviors and Their Motives, in University Students in the Health Area
}

\author{
Ávila-Escalante María Luisa, Aranda-González Irma Isela, \\ Pérez-Izquierdo Odette, Cruz-Bojórquez Reyna María*
}

Faculty of Medicine, Autonomous University of Yucatan, Yucatan, Mexico

Email: *reyna.cruz@corrreo.uady.mx

How to cite this paper: Luisa, Á.-E.M., Isela, A.-G.I., Odette, P.-I. and María, C.-B.R. (2020) Ávila-Escalante María Luisa, Aranda-González Irma Isela, Pérez-Izquierdo Odette, Cruz-Bojórquez Reyna María. Advances in Sexual Medicine, 10, 1-21. https://doi.org/10.4236/asm.2020.101001

Received: November 12, 2019

Accepted: January 10, 2020

Published: January 13, 2020

Copyright $\odot 2020$ by author(s) and Scientific Research Publishing Inc. This work is licensed under the Creative Commons Attribution International License (CC BY 4.0).

http://creativecommons.org/licenses/by/4.0/

\begin{abstract}
Sexually transmitted infections (STIs) and unwanted pregnancy (UP) are becoming a problem that affects significantly the younger segment of the population so, not only in the aspect of health, but in the development of its future life both emotional and school and work. Despite easy access to information, young people still have risky sexual practices. This research highlights protective practices with the aim of developing information and training tools that help them avoid risky behaviors that lead to dangerous situations in health and its future. It was a descriptive study with students who have recently entered of the Faculty of Medicine enrolled in school cycle in 2015 in the bachelor's degree in Medicine and surgery, Nutrition and dietetics, and Rehabilitation programs who agreed to participate by letter of informed consent to respond to the Instrument for the Evaluation of Psychological Variables and Sexual Risk Behaviors. There were 221 participants, 166 in Medicine and surgery, 28 in Nutrition and dietetics, and 27 in Rehabilitation with an average of 18.6 years, $51 \%$ male and $49 \%$ female. A protective behavior was not having had sex with penetration (72.3\%), due to wanting to have them with whom they are in love and to avoid STIs more frequently in female; another protective behavior was not having had oral sex with occasional partners or unprotected sex workers (15.4\%); the reasons were to have wanted to use and that the couple asked him to use it, to avoid sexually transmitted infections because the couple's sexual history is unknown. Regarding the likelihood of having sexual penetration (SP), participants who have not had it were found that: the men had less possibility to inquire about their partner's sexual history, to reject the proposal to have SP and to refuse caresses in sensitive areas of the woman's body; when asked about the likelihood of asking your partner to use a condom in their sexual relations, both men and women agreed that it would be quite likely that they would do so, more frequently in women. It concludes by emphasizing that prevention remains the cheapest, easiest, most
\end{abstract}


reliable and safest tool against STIs and UP.

\section{Keywords}

Protective Sexual Behaviors, University Students, Sexuality

\section{Introduction}

\subsection{Sexual Behavior}

Sexual behaviors are complex psychological and physiological processes with their own characteristics that could manifest themselves from the most primitive impulses to the most sophisticated emotions; they are influenced by cultural and social situations, past and present and their expression; the sexuality is a dynamic process that changes throughout life where emotions and feelings, the body and the knowledge we have about it are involved [1].

These behaviors are related to eroticism, emotional bonding, reproduction and genetic and physical sex that, according to each person, will have different sexual behaviors that can be experienced in different forms such as heterosexuality, homosexuality, transsexuality, bisexuality or polyamory [2].

All individuals have the right to exercise their sexuality, to decide when to start their sexual activity, postpone it, its frequency and with whom to perform it; however, this workout also requires responsibility, which begins with being informed of protection methods to prevent possible negative consequences, such as unwanted pregnancies (UP) and the spread of sexually transmitted infections (STIs) [3].

According to the Mexican National Health and Nutrition Survey (ENSANUT) 2012, in Mexico, which is the last one that has included data on sexuality, $23 \%$ of the population from 12 to 19 years of age has started their sexual life, with a higher proportion of men (25.5\%) than of women (20.5\%). Regarding the use of condoms, $14.7 \%$ of men and $33 \%$ of women did not use during the first sexual intercourse [4].

Adolescence is the stage in which the onset of sexual intercourse occurs most [5] and it is very common not to use protection at that age, most of the time due to lack of information, although the socioeconomic aspect also influences, since it is more likely that a young man with greater education knows how to use and where to get a contraceptive or preservative than young people with limited resources who have less accessibility due to economic and cultural causes [6].

\subsection{Sexual Risk Behaviors and Protective Sexual Behaviors}

Young people have been considered as a healthy age group, but at present, lifestyles have been modified and these involve risky sexual behaviors such as the early onset of active sexual life, having multiple partners, having occasional partners, vaginal or anal penetration without a condom, the practice of oral sex 
without a condom, cunnilingus, anilingus and direct skin-skin or mucosa-skin contact, which are the cause of UP and STIs, situation that has been reported in different studies [7].

In Slovakia, a study was carried out to identify the psychological and behavioral factors associated with sexual risk behaviors in 832 young people whose age was 19 to 28 years; it was observed that $44 \%$ of men and $33 \%$ of women claimed to have had risky sexual practices under the influence of alcohol or a drug; $27 \%$ of men and $21 \%$ of women mentioned having 4 or more sexual partners; $72 \%$ of men and $81 \%$ of women have used the condom inconsistently; $9 \%$ of the men and $6 \%$ of the women had sex before the age of 16 [8].

At the University of Castilla-La Mancha, a study was conducted with 262 young students of social work and education; it was found that $90 \%$ had already had sex at 16.4 years on average. $86 \%$ used a condom during the first relationship. $16 \%$ reported having had sexual relationships with occasional partners despite the fact that $77.4 \%$ of students consider themselves sufficiently informed on issues of sexuality [9].

Estimates of the Joint United Nations Program on HIV/AIDS (UNAIDS 2010), 33 million people in the world were living with HIV, numbers that continue to increase. The most worrying thing is that $50 \%$ of infections by this virus are acquired between 15 and 24 years of age [10].

The increase in STIs is a source of concern for WHO, because every year more than $15 \%$ of adolescents are infected and it is worrisome that about 560,000 adolescents between 15 and 24 years of age are living with HIV/AIDS in the world [11].

In Mexico, STIs are among the five main reasons for consultation in health centers of the first level of care and it is one of the first ten causes of morbidity in patients aged 15 to 44 [12].

A study conducted with 659 students from the Autonomous University of Tlaxcala (UAT), showed that $44 \%$ had sex at 17.6 years on average; $59 \%$ did not plan their first time, however, $55 \%$ used a condom. At the time of the survey, $72 \%$ used a condom and $26 \%$ another contraceptive method. On the other hand, $17 \%$ have combined alcohol or drug use during sexual intercourse and $4 \%$ of women surveyed have become pregnant [13].

According to the Mexican Program of Scholarships to Support Basic Education of Young Mothers and Pregnant Mothers (PROMAJOVEN by its acronym in Spanish) it was reported that the pregnancy rate in young women between 12 and 19 years was 79 per thousand, whose entities with the highest concentration were State of Mexico, Chiapas, Veracruz, Jalisco and Puebla. Among the consequences of the young people who go through this situation are family conflicts, psychological imbalances, lack of economic income, school dropout, social rejection, abandonment, repression and truncation in shaping a life project [14].

In another study conducted with 395 university students aged 18 - 28, the results show that $54 \%$ of men and $30 \%$ of women had already had their first sexual 
relationship. Regarding contraceptive methods, 59.9\% used a condom, $24 \%$ did not use any contraceptive method, $14 \%$ had interrupted intercourse and $3 \%$ used the rhythm method. As for sexual intercourse without vaginal intercourse, $52 \%$ of respondents reported having practiced it, of which $63 \%$ of men had it with their girlfriend, $33 \%$ on a passing adventure and $4 \%$ with a sex worker. Of the women $93 \%$ with his boyfriend, $4 \%$ with her girlfriend and $3 \%$ on a transitory adventure. Specifically, 59\% of women and $31 \%$ of men practiced oral sex and $6 \%$ of men and $1 \%$ of women practiced anal sex. Therefore, it was concluded to promote the information and use of condoms as a contraceptive and prevention method against sexually transmitted infections [15].

There are also preventive or protective sexual behaviors that minimize or eliminate the risk of contracting a STIs. These have positive short-term consequences that influence pleasant sexuality among those found: evade occasional couples and multiple couples; maintain sex with a stable partner; keep oral, vaginal or anal sex with condoms, the practice of cunnilingus and anilingus with protective plastic and evade sexual relations with people with ulcers or suppurations in their genitals [7].

\subsection{Reasons}

In this area of human sexuality, several factors that are associated with risky sexual practices have been reported, including the lack of maturity to exercise responsible sexuality, early onset of sexual life, low risk perception, pressures among the group of friends, increase in sexual partners, alcohol and drug abuse, ignorance of sexual rights and inadequate prevention programs. Although in recent years there has been greater publicity, this has not been enough, since young people do not yet exercise a free, responsible and pleasant sexuality that guides their coexistence and integral development [16].

A study conducted at the Autonomous University of the State of Mexico with 200 students of the bachelor's degrees of Health Education, International Trade, Systems Engineering and Transportation Engineering, showed that the use of condoms in young people is low, which places them as a group vulnerable to sexually transmitted infections and unwanted pregnancies even having all the information at hand [17]. The reasons were in $47.3 \%$ of men and $60 \%$ of women who did not have a condom at hand at the time of sexual intercourse, which reflects a lack of self-care when leaving the responsibility of their health to the couple. Another reason expressed by $42 \%$ of men and $25 \%$ of women is that it reduces sensitivity to the relationship.

These results show that as the years by, more young people begin their sexual life at an early age, which leads to a greater number of couples and sexual practices. Insecure and irresponsible sexual behaviors, as well as sexually transmitted infections and unplanned pregnancies, are health problems that occur daily and are known to young people due to the great ease of access to information to protect themselves; however, the incidence of sexually transmitted infections 
continues to increase.

The National Council for the Prevention and Control of AIDS (CONASIDA by its acronym in Spanish) in Mexico in 2012, reported 159,411 cases of people infected with HIV, of which young people up to 24 years constitute $10 \%$. In 2017, 14,117 new cases and more than 13,000 were registered for 2018. The states with the highest rate of new cases diagnosed until November in 2018 (per 100,000 population) of HIV were: Quintana Roo, Campeche and Veracruz and AIDS: Campeche, Quintana Roo and Yucatan [18].

Given this situation, it is crucial to know what are the behaviors and reasons that lead university students not to have sex with sexual penetration (SP), to always use protection in their oral sex, to not have occasional couples, etc. with the aim of guiding educational actions to have a greater impact, so the aim objective of the present study is to describe the protective sexual behaviors and their reasons in university students in the health area who have not had sex penetration.

\section{Methodology}

The project was presented to the authorities of the Faculty of Medicine and authorization was requested to carry it out. New students entering in Medicine and surgery, Nutrition and dietetics, and Rehabilitation programs of the 2015 school year met in their classrooms on the agreed dates for the application where they explained the purpose of the research; those who voluntarily agreed to participate signed the Informed Consent Letter and the Private Notice [19] [20], where they agreed to respond to the Instrument for the Evaluation of Psychological Variables and Sexual Risk Behaviors, elaborated and validated in the Mexican population by Piña, JA, Robles, S. and Rivera, BM (2007) ( $\alpha$ de Cronbach de 0.821). [19] [21]. This instrument is based on the psychological prevention model that allows on the one hand to identify why and under what circumstances peoples behave as they do and on the other hand, it provides the guideline to intervene trying to modify risk behaviors for prevention behaviors. The instrument consists of 28 questions divided into three sections, the first one addressed to people who have had sex with penetration; the second section to people who have not had sexual intercourse with penetration, but if they have experimented with oral sex and the third, directed to the second group, refers to the probability of having intercourse with sexual penetration in circumstances where there is a high probability. Of the total number of questions (28) of the instrument 14, they have a Likert format with 4 response options from "very determinant" with the number 1 of importance to "it was not determinant" with the number 4 . Five questions have two options of answer "Yes" or "No"; an age-related question with only one answer and 8 with 4 possible answers. All responses have the same value and only frequencies are reported [21].

Although sexual risk behaviors were also identified, the objective on the present work was to highlight protective sexual behaviors presented by the study population and were identified with the instrument. 
The data processing was carried out with the SPSS Statics v.22 program, where only the descriptive statistics were obtained: frequencies, percentages and measures of central tendency.

\section{Results}

The study population consisted of 221 students who have recently entered of the Faculty of Medicine of the Autonomous University of Yucatan in the 2015 school year, of which $75.1 \%$ (166) corresponded to the bachelor's degree in Medicine and surgery, $12.6 \%$ (28) in Nutrition and dietetics, and $12.3 \%$ (27) to Rehabilitation programs, of which 51\% (113) were men and 49\% (108) were women with average age of 18.68 years.

In Table 1, it can be observed that the first protector behavior in the students that formed the study population was not having had sex with penetration with a frequency of $72.3 \%$ in slightly higher proportion in women $(39.4 \%)$ than in men $(32.9 \%)$.

When the data are observed according to the bachelor's degree, this behavior occurred more frequently in the women of Nutrition and dietetics (7.2\%) and Rehabilitation (6.9\%) than in the men, while in the bachelor's degree of Medicine and surgery it was in the men (28.9\%).

The reasons that led these students not to have SP were: because they want to have sex with someone they are in love with (61.8\%) and not to acquire sexually transmitted infections (1.4\%).

Only $27.7 \%$ mentioned having had SP, twice the proportion of men $(18.1 \%)$ than women (9.6\%). In the bachelor's degree in Medicine and surgery $(14.0 \%)$ and Nutrition and dietetics $(3.2 \%)$ were men, who represented higher frequency, while in Rehabilitation were women (1.8\%)

Another protector behavior is not having unprotected oral sex (Table 2); of the study population that claimed not to have had SP, a low percentage $(8.2 \%)$ mentioned having had oral sex. The men (30.8\%) and women $(30.8 \%)$ of the

Table 1. Study population that has had sexual intercourse with sex and bachelor's penetration.

\begin{tabular}{cccccccc}
\hline \multirow{2}{*}{ Bachelor's Degree } & \multicolumn{5}{c}{ No } & \multicolumn{5}{c}{ Yes } & \multirow{2}{*}{ Total } \\
\cline { 2 - 7 } & $\mathbf{M}$ & $\mathrm{W}$ & Total & $\mathbf{M}$ & $\mathrm{W}$ & Total & \\
\hline \multirow{2}{*}{ Medicine and surgery } & 64 & 56 & 120 & 31 & 15 & 46 & 166 \\
& $(28.9 \%)$ & $(25.3 \%)$ & $(54.2 \%)$ & $(14.0 \%)$ & $(6.9 \%)$ & $(20.9 \%)$ & $(75.1 \%)$ \\
Nutrition and dietetics & 3 & 16 & 19 & 7 & 2 & 9 & 28 \\
& $(1.3 \%)$ & $(7.2 \%)$ & $(8.5 \%)$ & $(3.2 \%)$ & $(0.9 \%)$ & $(4.1 \%)$ & $(12.6 \%)$ \\
Rehabilitation & 6 & 15 & 21 & 2 & 4 & 6 & 27 \\
& $(2.7 \%)$ & $(6.9 \%)$ & $(9.6 \%)$ & $(0.9 \%)$ & $(1.8 \%)$ & $(2.7 \%)$ & $(12.3 \%)$ \\
Total & 73 & 87 & 160 & 40 & 21 & 61 & 221 \\
& $(32.9 \%)$ & $(39.4 \%)$ & $(72.3 \%)$ & $(18.1 \%)$ & $(9.6 \%)$ & $(27.7 \%)$ & $(100 \%)$ \\
\hline
\end{tabular}

M: men; W: women. Source: "Results of the application of the instrument for the evaluation of psychological variables and risky sexual behaviors" Piña J.A. y col., in 2007. 
Table 2. Study population that has had oral sex, by sex and degree.

\begin{tabular}{cccccccc}
\hline \multirow{2}{*}{ Options } & \multicolumn{2}{c}{$\begin{array}{c}\text { Medicine and } \\
\text { surgery }\end{array}$} & \multicolumn{2}{c}{$\begin{array}{c}\text { Nutrition and } \\
\text { dietetics }\end{array}$} & Rehabilitation & \multirow{2}{*}{ Total } \\
\cline { 2 - 6 } & M & W & M & W & M & W & \\
\hline My girls/boy friend & 4 & 4 & - & 1 & 1 & - & 10 \\
From a friend & $(30.8 \%)$ & $(30.8 \%)$ & & $(7.7 \%)$ & $(7.7 \%)$ & & $(77.0 \%)$ \\
Of eventual couples who & 2 & - & 1 & & & - & 3 \\
didn't know much & - & - & - & - & - & - & - \\
From sex workers & - & - & - & - & - & - & - \\
Total & 6 & 4 & 1 & 1 & 1 & - & 13 \\
& $(46.1 \%)$ & $(30.8 \%)$ & $(7.7 \%)$ & $(7.7 \%)$ & $(7.7 \%)$ & & $(100 \%)$ \\
\hline
\end{tabular}

M: men; W: women. Source: "Results of the application of the instrument for the evaluation of psychological variables and risky sexual behaviors" Piña J.A. y col., in 2007.

bachelor's degree in Medicine and surgery are the ones who presented the most frequency, followed by the men and women of the bachelor's degree in Nutrition and dietetics (7.7\% respectively) and in the end the men of the bachelor's degree in Rehabilitation (7.7\%).

It could be observed as another protective factor that $100 \%$ of the students, who responded to having had oral sex, did not practice it with occasional couples or sex workers, $77 \%$ mentioned having them with their boyfriend or girlfriend and $23 \%$ with a friend or friend (Table 2), however, this does not guarantee to be exempt from acquiring STIs.

Of the students who mentioned having had oral sex, a very low percentage (15.4\%) used condoms, of which $7.7 \%$ correspond to men of the bachelor's degree in Medicine and surgery, while the other $7.7 \%$ corresponds to women of the bachelor degree in Nutrition and dietetics. The reasons that led them to use it were having wanted to use it and that the couple asked him to use it, to avoid sexually transmitted infections because they do not know the sexual history of the couple.

This situation is worrisome since $84.6 \%$ acknowledged not protecting themselves with condoms in their oral sex, a situation that is more frequent among men (38.5\%) and women (30.7\%) of the bachelor's degree in Medicine and surgery and men of the bachelor's degrees in Nutrition and dietetics (7.7\%) and Rehabilitation (7.7\%), as can be seen in Table 3.

It is important to consider that, in young people, sexual health is a difficult problem to control because sexuality involves emotions and feelings, so there is a high probability that SP will occur at any time.

Below, we present the data of 144 students who have not had SP and who answered the last part of the questionnaire where it is requested to imagine a situation where there is a high possibility of having SP.

In Table 4, it can be observed in a general way, that in men it is more or less 
Table 3. Condom use of the study population in their oral sex, by sex and degree.

\begin{tabular}{cccccccc}
\hline \multirow{2}{*}{ Bachelor's Degree } & \multicolumn{3}{c}{ No } & \multicolumn{5}{c}{ Yes } & \multirow{2}{*}{ Total } \\
\cline { 2 - 7 } & $\mathbf{M}$ & W & Total & M & W & Total & \\
\hline Medicine and surgery & 5 & 4 & 9 & 1 & & 1 & 10 \\
& $(38.5 \%)$ & $(30.7 \%)$ & $(69.2 \%)$ & $(7.7 \%)$ & - & $(7.7 \%)$ & $(76.9 \%)$ \\
Nutrition and dietetics & 1 & & 1 & & 1 & 1 & 2 \\
& $(7.7 \%)$ & - & $(7.7 \%)$ & - & $(7.7 \%)$ & $(7.7 \%)$ & $(15.4 \%)$ \\
Rehabilitation & 1 & & 1 & & & & 1 \\
& $(7.7 \%)$ & - & $(7.7 \%)$ & - & - & - & $(7.7 \%)$ \\
Total & 7 & 4 & 11 & 1 & 1 & 2 & 13 \\
& $(53.9 \%)$ & $(30.7 \%)$ & $(84.6 \%)$ & $(7.7 \%)$ & $(7.7 \%)$ & $(15.4 \%)$ & $(100 \%)$ \\
\hline
\end{tabular}

M: men; W: women. Source: "Results of the application of the instrument for the evaluation of psychological variables and risky sexual behaviors" Piña J.A. y col., in 2007.

Table 4. Probability of investigating the sexual history of the couple's.

\begin{tabular}{|c|c|c|c|c|c|}
\hline Options & Sex & $\begin{array}{c}\text { Medicine and } \\
\text { surgery }(n=107)\end{array}$ & $\begin{array}{c}\text { Nutrition and } \\
\text { dietetics }(N=17)\end{array}$ & $\begin{array}{l}\text { Rehabilitation } \\
\quad(n=20)\end{array}$ & $\begin{array}{c}\text { Total } \\
(\mathrm{N}=144)\end{array}$ \\
\hline \multirow{2}{*}{ Not at all likely } & M & $\begin{array}{c}14 \\
(9.7 \%)\end{array}$ & 0 & $\begin{array}{c}1 \\
(0.7 \%)\end{array}$ & $\begin{array}{c}15 \\
(10.4 \%)\end{array}$ \\
\hline & $\mathrm{W}$ & $\begin{array}{c}7 \\
(4.8 \%)\end{array}$ & $\begin{array}{c}4 \\
(2.8 \%)\end{array}$ & $\begin{array}{c}2 \\
(1.4 \%)\end{array}$ & $\begin{array}{c}13 \\
(9.0 \%)\end{array}$ \\
\hline \multirow{2}{*}{$\begin{array}{c}\text { More or less } \\
\text { likely }\end{array}$} & M & $\begin{array}{c}24 \\
(16.7 \%)\end{array}$ & $\begin{array}{c}2 \\
(1.4 \%)\end{array}$ & $\begin{array}{c}3 \\
(2.1 \%)\end{array}$ & $\begin{array}{c}29 \\
(20.2 \%)\end{array}$ \\
\hline & $\mathrm{W}$ & $\begin{array}{c}21 \\
(14.7 \%)\end{array}$ & $\begin{array}{c}5 \\
(3.4 \%)\end{array}$ & $\begin{array}{c}1 \\
(0.7 \%)\end{array}$ & $\begin{array}{c}27 \\
(18.8 \%)\end{array}$ \\
\hline \multirow{2}{*}{ Very likely } & M & $\begin{array}{c}10 \\
(6.9 \%)\end{array}$ & 0 & $\begin{array}{c}1 \\
(0.7 \%)\end{array}$ & $\begin{array}{c}11 \\
(7.6 \%)\end{array}$ \\
\hline & $\mathrm{W}$ & $\begin{array}{c}6 \\
(4.1 \%)\end{array}$ & $\begin{array}{c}2 \\
(1.4 \%)\end{array}$ & $\begin{array}{c}6 \\
(4.2 \%)\end{array}$ & $\begin{array}{c}14 \\
(9.7 \%)\end{array}$ \\
\hline \multirow[b]{2}{*}{ Quite likely } & M & $\begin{array}{c}7 \\
(4.9 \%)\end{array}$ & 0 & 0 & $\begin{array}{c}7 \\
(4.9 \%)\end{array}$ \\
\hline & $\mathrm{W}$ & $\begin{array}{c}18 \\
(12.5 \%)\end{array}$ & $\begin{array}{c}4 \\
(2.8 \%)\end{array}$ & $\begin{array}{c}6 \\
(4.1 \%)\end{array}$ & $\begin{array}{c}28 \\
(19.4 \%)\end{array}$ \\
\hline Total & & $\begin{array}{c}107 \\
(74.3 \%)\end{array}$ & $\begin{array}{c}17 \\
(11.8 \%)\end{array}$ & $\begin{array}{c}20 \\
(13.9 \%)\end{array}$ & $\begin{array}{c}144 \\
(100.0 \%)\end{array}$ \\
\hline
\end{tabular}

M: men; W: women. Source: "Results of the application of the instrument for the evaluation of psychological variables and risky sexual behaviors" Piña J.A. y col., in 2007.

likely to inquire about the sexual history of their couples $(20.2 \%)$, while, in women, they are quite likely to do so (19.4\%).

When the results by bachelor's degree are observed, it can be seen that the men and women of the bachelor's degree in Medicine and surgery, and Nutrition and dietetics and the men of the degree in Rehabilitation, mentioned that they are less likely to inquire about the sexual background of their partner, while rehabilitation women are very likely to do so.

Table 5 shows in general that in men there is a lower probability of rejecting 
Table 5. Probability of rejecting the proposal of having sex.

\begin{tabular}{|c|c|c|c|c|c|}
\hline Options & Sex & $\begin{array}{c}\text { Medicine and } \\
\text { surgery }(n=107)\end{array}$ & $\begin{array}{c}\text { Nutrition and } \\
\text { dietetics }(n=17)\end{array}$ & $\begin{array}{l}\text { Rehabilitation } \\
\qquad(\mathrm{n}=20)\end{array}$ & $\begin{array}{c}\text { Total } \\
(\mathrm{N}=144)\end{array}$ \\
\hline \multirow{4}{*}{ Not at all likely } & \multirow{2}{*}{$\mathrm{M}$} & 8 & 1 & \multirow{2}{*}{0} & 9 \\
\hline & & $5.6 \%$ & $0.7 \%$ & & $6.3 \%$ \\
\hline & \multirow[b]{2}{*}{ W } & & 1 & \multirow[b]{2}{*}{0} & 3 \\
\hline & & $1.4 \%$ & $0.7 \%$ & & $2.1 \%$ \\
\hline \multirow{4}{*}{ More or less likely } & \multirow{2}{*}{$\mathrm{M}$} & 28 & \multirow{2}{*}{0} & 4 & 32 \\
\hline & & $19.4 \%$ & & $2.8 \%$ & $22.2 \%$ \\
\hline & \multirow{2}{*}{$\mathrm{W}$} & 14 & 2 & 4 & 20 \\
\hline & & $9.7 \%$ & $1.4 \%$ & $2.8 \%$ & $13.9 \%$ \\
\hline \multirow{4}{*}{ Very likely } & \multirow{2}{*}{$\mathrm{M}$} & 11 & \multirow{2}{*}{0} & 1 & 12 \\
\hline & & $7.6 \%$ & & $0.7 \%$ & $8.3 \%$ \\
\hline & \multirow[b]{2}{*}{$\mathrm{W}$} & 9 & 5 & 3 & 17 \\
\hline & & $6.3 \%$ & $3.5 \%$ & $2.1 \%$ & $11.8 \%$ \\
\hline \multirow{4}{*}{ Quite likely } & \multirow{2}{*}{$\mathrm{M}$} & 8 & 1 & \multirow{2}{*}{0} & 9 \\
\hline & & $5.6 \%$ & $0.7 \%$ & & $6.3 \%$ \\
\hline & \multirow{2}{*}{$\mathrm{W}$} & 27 & 7 & 8 & 42 \\
\hline & & $18.7 \%$ & $4.8 \%$ & $5.5 \%$ & $29.1 \%$ \\
\hline \multirow{2}{*}{ Total } & & 107 & 17 & 20 & 144 \\
\hline & & $74.3 \%$ & $11.8 \%$ & $13.9 \%$ & $100.0 \%$ \\
\hline
\end{tabular}

M: men; W: women. Source: "Results of the application of the instrument for the evaluation of psychological variables and risky sexual behaviors” Piña J.A. y col., in 2007

the proposal to have sexual relations $(22.2 \%)$, while women are quite likely to do so $(29.1 \%)$.

When the results are observed by bachelor's degrees, it can be affirmed that in the bachelor's degree in Medicine and surgery and Rehabilitation it is more or less likely than men reject the proposal to have sexual relations unlike women in whom it is quite probable. In the bachelor's degree in Nutrition and dietetics, the same proportion of men consider it not at all likely and quite likely to reject the proposal of having sex, while in women it is quite likely to do so.

The probability of rejecting the proposal of reaching caresses of sensitive areas of the body was generally more or less likely in men (18.8\%) and quite likely in women (25.0\%), according to the results presented in Table 6.

In the bachelor's degree in Medicine and surgery, men consider it more or less likely to do so, while women mentioned that it is quite likely. In the bachelor's degree in Nutrition and dietetics, there is an equal proportion of men who mentioned that it is not at all likely and very likely, unlike the women who mentioned that they are quite likely to do so. In the bachelor's degree in Rehabilitation, both men and women felt that they would be more or less likely to reject the proposal to reach caresses in sensitive areas of their body.

In Table 7, it can be observed that in general both men (31.2\%) and women $(52.1 \%)$ are quite likely ask your partner to use the condom in their sexual intercourse. In the bachelor's degrees in Medicine and surgery and Rehabilitation 
Table 6. Probability of rejecting the proposal to reach caresses of sensitive areas of your body.

\begin{tabular}{|c|c|c|c|c|c|}
\hline Options & Sex & $\begin{array}{c}\text { Medicine and } \\
\text { surgery }(n=107)\end{array}$ & $\begin{array}{c}\text { Nutrition and } \\
\text { dietetics }(n=17)\end{array}$ & $\begin{array}{l}\text { Rehabilitation } \\
\quad(\mathrm{n}=20)\end{array}$ & $\begin{array}{c}\text { Total } \\
(\mathrm{N}=144)\end{array}$ \\
\hline \multirow{2}{*}{ Not at all likely } & M & $\begin{array}{c}16 \\
(11.1 \%)\end{array}$ & $\begin{array}{c}1 \\
(0.7 \%)\end{array}$ & $\begin{array}{c}2 \\
(1.4 \%)\end{array}$ & $\begin{array}{c}19 \\
(13.2 \%)\end{array}$ \\
\hline & W & $\begin{array}{c}3 \\
(2.1 \%)\end{array}$ & $\begin{array}{c}1 \\
(0.7 \%)\end{array}$ & $\begin{array}{c}1 \\
(0.7 \%)\end{array}$ & $\begin{array}{c}5 \\
(3.4 \%)\end{array}$ \\
\hline \multirow{2}{*}{ More or less likely } & M & $\begin{array}{c}24 \\
(16.7 \%)\end{array}$ & 0 & $\begin{array}{c}3 \\
(2.1 \%)\end{array}$ & $\begin{array}{c}27 \\
(18.8 \%)\end{array}$ \\
\hline & W & $\begin{array}{c}15 \\
(10.4 \%)\end{array}$ & $\begin{array}{c}4 \\
(2.8 \%)\end{array}$ & $\begin{array}{c}7 \\
(4.9 \%)\end{array}$ & $\begin{array}{c}26 \\
(18.1 \%)\end{array}$ \\
\hline \multirow{2}{*}{ Very likely } & M & $\begin{array}{c}9 \\
(6.2 \%)\end{array}$ & $\begin{array}{c}1 \\
(0.7 \%)\end{array}$ & 0 & $\begin{array}{c}10 \\
(6.9 \%)\end{array}$ \\
\hline & $\mathrm{W}$ & $\begin{array}{c}11 \\
(7.6 \%)\end{array}$ & $\begin{array}{c}2 \\
(1.4 \%)\end{array}$ & $\begin{array}{c}2 \\
(1.4 \%)\end{array}$ & $\begin{array}{c}15 \\
(10.4 \%)\end{array}$ \\
\hline \multirow{2}{*}{ Quite likely } & M & $\begin{array}{c}6 \\
(4.2 \%)\end{array}$ & 0 & 0 & $\begin{array}{c}6 \\
(4.2 \%)\end{array}$ \\
\hline & W & $\begin{array}{c}23 \\
(16.0 \%)\end{array}$ & $\begin{array}{c}8 \\
(5.5 \%)\end{array}$ & $\begin{array}{c}5 \\
(3.5 \%)\end{array}$ & $\begin{array}{c}36 \\
(25.0 \%)\end{array}$ \\
\hline Total & & $\begin{array}{c}107 \\
(74.3 \%)\end{array}$ & $\begin{array}{c}17 \\
(11.8 \%)\end{array}$ & $\begin{array}{c}20 \\
(13.9 \%)\end{array}$ & $\begin{array}{c}144 \\
(100.0 \%)\end{array}$ \\
\hline
\end{tabular}

M: men; W: women. Source: "Results of the application of the instrument for the evaluation of psychological variables and risky sexual behaviors" Piña J.A. y col., in 2007.

Table 7. Probability of asking the couple to use a condom.

\begin{tabular}{|c|c|c|c|c|c|}
\hline Options & Sex & $\begin{array}{c}\text { Medicine and } \\
\text { surgery }(n=107)\end{array}$ & $\begin{array}{c}\text { Nutrition and } \\
\text { dietetics }(n=17)\end{array}$ & $\begin{array}{l}\text { Rehabilitation } \\
\quad(\mathrm{n}=20)\end{array}$ & $\begin{array}{c}\text { Total } \\
(\mathrm{N}=144)\end{array}$ \\
\hline \multirow{2}{*}{ Not at all likely } & $\mathrm{H}$ & $\begin{array}{c}1 \\
(0.7 \%)\end{array}$ & $\begin{array}{c}1 \\
(0.7 \%)\end{array}$ & 0 & $\begin{array}{c}2 \\
(1.4 \%)\end{array}$ \\
\hline & M & $\begin{array}{c}2 \\
(1.4 \%)\end{array}$ & 0 & $\begin{array}{c}1 \\
(0.7 \%)\end{array}$ & $\begin{array}{c}3 \\
(2.1 \%)\end{array}$ \\
\hline \multirow{2}{*}{$\begin{array}{c}\text { More or less } \\
\text { likely }\end{array}$} & $\mathrm{H}$ & $\begin{array}{c}4 \\
(2.8 \%)\end{array}$ & 0 & 0 & $\begin{array}{c}4 \\
(2.8 \%)\end{array}$ \\
\hline & M & 0 & 0 & 0 & 0 \\
\hline \multirow{2}{*}{ Very likely } & $\mathrm{H}$ & $\begin{array}{c}9 \\
(6.2 \%)\end{array}$ & 0 & $\begin{array}{c}2 \\
(1.4 \%)\end{array}$ & $\begin{array}{c}11 \\
(7.6 \%)\end{array}$ \\
\hline & M & $\begin{array}{c}1 \\
(0.7 \%)\end{array}$ & $\begin{array}{c}1 \\
(0.7 \%)\end{array}$ & $\begin{array}{c}2 \\
(1.4 \%)\end{array}$ & $\begin{array}{c}4 \\
(2.8 \%)\end{array}$ \\
\hline \multirow{2}{*}{ Quite likely } & $\mathrm{H}$ & $\begin{array}{c}41 \\
(28.4 \%)\end{array}$ & $\begin{array}{c}1 \\
(0.7 \%)\end{array}$ & $\begin{array}{c}3 \\
(2.1 \%)\end{array}$ & $\begin{array}{c}45 \\
(31.2 \%)\end{array}$ \\
\hline & M & $\begin{array}{c}49 \\
(34.1 \%)\end{array}$ & $\begin{array}{c}14 \\
(9.7 \%)\end{array}$ & $\begin{array}{c}12 \\
(8.3 \%)\end{array}$ & $\begin{array}{c}75 \\
(52.1 \%)\end{array}$ \\
\hline Total & & $\begin{array}{c}107 \\
(74.3 \%)\end{array}$ & $\begin{array}{c}17 \\
(11.8 \%)\end{array}$ & $\begin{array}{c}20 \\
(13.9 \%)\end{array}$ & $\begin{array}{c}144 \\
(100.0 \%)\end{array}$ \\
\hline
\end{tabular}

M: men; W: women. Source: "Results of the application of the instrument for the evaluation of psychological variables and risky sexual behaviors" Piña J.A. y col., in 2007. 
the results are similar, both men and women consider it quite probable that they ask their partners to use a condom; while, in the bachelor's degree in Nutrition and dietetics, the same proportion of men felt that it would be unlikely and quite likely to do so, women consider it quite likely to ask their partners to use condoms in their sexual relations.

\section{Discussion}

Currently, the increase in sexually transmitted infections and unwanted pregnancies are becoming a problem that is significantly affecting the youngest sector of the population, not only in the aspect of health, but in development of their future life both emotional and school and work.

Some university research has made it clear that despite the information they have access to now, with great ease, they continue to have risky sexual practices, which urgently demands preventive actions at all levels of the school system. Most of these investigations have been based on risk behaviors [22]. This paper highlights protective practices with the aim of developing information and training tools that help them avoid risky behaviors that lead to dangerous situations for health and their future.

The results show that a high percentage $(72.3 \%)$ of the population of students who participated in the study had not had sex with penetration, being the average age 18.7 years, a situation that attracts attention because the current trend in the population young people start their active sex life between 15 and 18, as mentioned in the results of different studies [23] [24].

In the First National Survey on Sex conducted by Mitofsky in 2004 in Mexico, it was found that the average age of onset of active sexual life in the participating adolescents was 17.6 years, presenting a higher proportion between 15 - 18 years, being the frequency higher in men (79.6\%) than in women (51.7\%) [25].

In a study conducted at the National Autonomous University of Mexico (UNAM), where 990 students from their different campuses were interviewed, it was found that the age of onset of sexual relations was 17.3, a situation that is different from the results of the present study [26]. However, according to the National Youth Survey 2010, in Yucatan it was found that $84.8 \%$ of the population surveyed decided not to have sexual relations, a figure slightly higher than in the present study [27].

The very determining reasons that the students mentioned for not having SP were: because they want to have SP with whom they are in love, for men $(22.1 \%)$ and women $(22.7 \%)$ of the bachelor degree in Medicine and surgery; this same reason was found in women (8.4\%) of the bachelor's degree in Nutrition and dietetics and men (1.4\%) and women (7.1\%) of the bachelor's degree in Rehabilitation. The men (1.4\%) of the bachelor degree in Nutrition and dietetics considered it a very decisive reason to avoid a sexually transmitted infection. Other reasons were: to avoid pregnancy, "because I want to put into practice the way I have been educated", among others. 
This situation may be due to sex education programs in schools that have sensitized adolescents to the problems involved in acquiring an STIs or the responsibility of being a father or mother in the early stages of life.

Of the study population that claimed not to have had sex with penetration (160 people), only $8.2 \%$ (13 people) acknowledged having had oral sex. These results differ with a study conducted by Lama et al. (2008), where $30 \%$ of the participants mentioned having oral relationships [28].

Oral sex than anal sex, the use of sex toys, group sex, etc., is part of the so-called alternate sexual practices that are behavioral manifestations within the sexual field whose goal is the satisfaction of the participants according to DSM-IV [29], are influenced by many factors such as personal (self-esteem, moral, self-concept), cultural (religion, uses and customs), social norms (family, friends, community), education and gender, which are embodied in a concept known as permissiveness, which is defined as a flexible attitude towards various sexual practices, in the presence or absence of emotional bonding, whose purpose is satisfaction and not reproduction as in stages historical past [30]. It has reached a point where, as Weeks (2002) would say, "masculinity-femininity, normality-abnormality and the nature of intimate life are being subject to profound transformations, new ideologies that generate a more liberal and of greater acceptance [31]. "This is reflected in different studies, in the National Survey on Sex conducted in Mexico, more than $7 \%$ of participants mentioned having had group sex; one in ten used sex toys; half considered masturbation and oral sex as usual practices and one-tenth of homosexual relations [25] [32].

With regard to gender, $61.5 \%$ of the participants who mentioned having had oral sex were men and $38.5 \%$ women, this coincides with a qualitative study conducted by Cedillo (2015), with 434 students from two universities, where he found that men are the ones who practice oral sex the most, they like it better and they like it more [33].

On the other hand, it is worrisome that of the study population that had oral sex, $84.6 \%$ recognized that they did not use a condom, this result coincides with that found in the study by Valdez Montero, C. et al. (2015), mentioned above where it was found that $87.3 \%$ of the study population did not use a condom when they had oral sex [34]. This may be due in part to this type of relationship they had with people with whom they have an emotional bond and a close and long-term treatment; $77 \%$ mentioned that it was with their boyfriend or girlfriend and $23 \%$ with a friend. These results differ in frequency from that reported by De la Rubia J where $52 \%$ of the students practiced oral sex and agree that they preferably had this type of relationship with the partner [15].

Regarding imagining being in a situation with a high probability of having SP, the participants who have not had SP had the following results: the men had less chance to inquire about their partner's sexual history, to reject the proposal to have SP and reject caresses in sensitive areas of the body than women. This situation may be due to the fact that men have greater permissiveness than women, 
which is consistent with the results of Whisman (1996), Ubillos et al. (2000) and Yost and Zurbriggen (2006) [35] [36] [37]. As Cañizo and Salinas comment in their study in 2010, "a possible explanation of the above could be due to the prevalence of machismo within Mexican society, since the value of men, in some cases, could be based on the number of partner, the early onset of their sexuality and the variability of the practices they perform [38]. On the other hand, society, from home schooling, may teach women more conservative and rigid codes of behavior, which would generate in them little openness in terms of sexuality and lack of recognition of their erotic fantasies and desires sexual, which probably increases their guilt in these matters". However, when asked about the likelihood of asking your partner to use a condom in their sexual relationships, both men and women agreed that it would be quite likely that they would do so, more frequently in women.

Undoubtedly, university students are in a very important stage for their development that requires sexual education that allows knowledge of your body and its most informed and responsible sexuality. Higher Education Institutions face a great challenge, not only to train young people as professionals, but to promote healthy behaviors that permanently impact their quality of life.

\section{Conclusions}

1) Protective sexual practices were: abstinence, oral sex with condoms and having oral sex with known partners.

2) The reasons for not having sexual practice with penetration were: wanting to have SP with those in love and preventing STIs.

3) Regarding the probability of having SP, it was found that men are less likely to explore their partner's sexual history, reject the proposal to have SP and caresses in sensitive areas of the body compared to women. And like them, it is quite likely that they will ask their partner to use a condom in their SP.

4) The results allow us to conclude that the behaviors that protect against STIs and UP are the result of prevention, as a reliable and safe tool to maintain health and life.

\section{Limitations}

- The study is only valid for the population under investigation. It is not representative for any population.

- The fact that participation in the study is voluntary can promote the exclusion of individuals with risky behaviors, who may refuse to participate.

- There may be many other reasons; this study included the most common previously identified in students in the area of health.

\section{Acknowledgements}

We thank the Medicine and surgery, Nutrition and dietetics and Rehabilitation undergraduate program students who collaborated in the data collection, the 
academic and administrative authorities of the Faculty of Medicine of the Autonomous University of Yucatan, for all their support and facilities granted in the making of this project.

\section{Conflicts of Interest}

The authors declare no conflicts of interest regarding the publication of this paper.

\section{References}

[1] Federación Española de Sociedades de Sexología (2016) La Conducata Sexual en Apartado de Salud Sexual. https://www.fess.org.es/salud-sexual

[2] Organización Mundial de la Salud (2016) Salud Sexual. http://www.who.int/topics/sexual_health/es

[3] IMSS-Conafe Editores. (2016) Hablemos de Sexualidad. Guía para instructores comunitarios y promotores de educación inicial.

http://www.imss.gob.mx/sites/all/statics/salud/yosimecuido/Libro-Hablemos-de-Se xualidad.pdf

[4] Gutiérrez, J.P., Rivera, J., Shamah-Levy, T., Oropeza, C. and Hernández-Ávila, M. (2012) Encuesta Nacional de Salud y Nutrición 2012. Instituto Nacional de Salud Pública, Cuernavaca. https://ensanut.insp.mx/encuestas/ensanut2012/informes.php

[5] Orcasita, L. and Uribe, A. (2009) Conductas sexuales de riesgo en estudiantes universitarios de la ciudad de Cali-Colombia. Revista Virtual Universidad Católica del Norte, 27, 1-31.

[6] Weiti, C. (2005) Inicio de la vida sexual y reproductiva. Papeles de la población, 11, 143-176.

[7] Braun-Courville, D.K. and Rojas, M. (2009) Exposure to Sexually Explicit Websites and Adolescent Sexual Attitudes and Behaviors. Journal of Adolescent Health, 45, 156-162. https://doi.org/10.1016/j.jadohealth.2008.12.004

[8] Kalina, O., Geckova, A.M., Jarcuska, P., Orosova, O., van Dijk, J.P. and Reijneveld, S.A. (2009) Psychological and Behavioural Factors Associated with Sexual Risk Behaviour among Slovak Students. BMC Public Health, 9, 15.

https://doi.org/10.1186/1471-2458-9-15

[9] Yubero, M., Larrañaga, E. and Yubero, S. (2013) Actitudes y comportamiento sexual de riesgo de embarazo en jóvenes universitarios. Revista de psicología del niño y adolescente, 4, 11-29.

[10] Programa Conjunto de las Naciones Unidas sobre VIH (CONUSIDA) (2010) Informe de ONUSIDA sobre la epidemia mundial de sida 2010.

http://www.unaids.org/globalreport/Global_report_es.htm

[11] Organizacion Mundial para la Salud (2011) Salud y desarrollo del niño y del adolescente.

http://www.who.int/maternal_child_adolescent/topics/adolescence/dev/es

[12] Secretaría de Salud (2008) Enfermedades de transmisión sexual en el adolescente y adulto que producen ulceras genitales, herpes, sífilis, chancroide, linfagranuloma venéreo y granuloma inguinal. México: Secretaria de salud.

http://www.cenetec.salud.gob.mx/descargas/gpc/CatalogoMaestro/094_GPC_ETSad olescyadulto/ENF_SEXUALES_EVR_CENETEC2.pdf 
[13] Lumbreras Delgado, I., Moctezuma Ayala, M.G., Dosamantes Carrasco, L.D., Medina Hernández, M.A., Cervantes Rodríguez, M., López Loyo, M.R. and Méndez Hernández, P. (2010) Estilos de vida y riesgos para la salud en estudiantes universitarios: Hallazgos para la prevención. Revista UNAM, 10, 1-10.

[14] PROMAJOVEN (2012) Embarazo adolescente y madres jóvenes en México. https://www.promajoven.sep.gob.mx/files/materiales/Embarazo_Adolescente.pdf

[15] De la Rubia, J. (2007) Conducta sexual y uso del preservativo en estudiantes universitarios. Medicina Universitaria, 9, 173-180.

[16] Velásquez, V. and Bedoya, S. (2010) Los jóvenes: Una población vulnerable del VIH/Sida. Medicina UPB, 2, 144-154.

[17] Pérez, D. and Fonseca, C. (2011) Libertad y responsabilidad en la vida sexual de los jóvenes universitarios. Revista Digital Universitaria, 12, 1-19. http://www.revista.unam.mx/vol.12/num11/art109/art109.pdf

[18] Secretaria de salud (2012) Vigilancia Epidemiológica de casos de VIH/SIDA en México. Registro Nacional de casos de SIDA. Actualización al 09 de noviembre de 2018, Día mundial del SIDA.

https://www.gob.mx/cms/uploads/attachment/file/415154/RN_D_a_mudial_sida20 18.pdf

[19] SEGOB (2017) Diario Oficioal de la Federación. Ley General de Salud. 3. http://www.salud.gob.mx/unidades/cdi/legis/lgs/LEY_GENERAL_DE_SALUD.pdf

[20] SEGOB (2010) Ley Federal de Protección de Datos Personales. Diario Oficial de la Federación. 4

http://dof.gob.mx/nota_detalle.php?codigo $=5150631 \&$ fecha $=05 / 07 / 2010$

[21] Piña, J.A., Robles, S. and Rivera, B.M. (2007) Instrumento para la evaluación de variables psicológicas y comportamientos sexuales de riesgo en jóvenes de dos centros universitarios de México. Revista Panamericana Salud Publica, 22, 295-303. https://doi.org/10.1590/S1020-49892007001000001

[22] Alemán, I., Cortes, I. and Pérez, R. (2013) Conocimientos y comportamientos sobre planificación familiar y enfermedades de transmisión sexual en estudiantes de enfermería. Boletín Médico Hospital infantil México, 70, 19-25.

[23] Cortes Alfaro, A., Ochoa Soto, R., Lantero Abreu, M.I., Suárez Medina, R., Cruz Traconte, E., Llorente Cabrera, Y. and Joaquín Joanes, J. (2015) HIV Infection in the Adolescence, Cuba, 1987 to December 2014: An Epidemiological Approach. Jacobs Journal of Allergy and Immunology, 3, 21.

[24] Pascual González, Y., Pérez Avilán, G.T., Puentes Vásquez, S.M. and Avilán Rovira, J.M. (2010) Relaciones sexuales en adolescentes y fuentes de información para su educación sexual. Acta Científica Estudiantil, 8, 72-77.

[25] Consulta Mitofsky (2004) Primera encuesta nacional de sexo. Estudio de opinión en viviendas. http://www.consulta.com.mx

[26] Hurtado, M.T. and Olvera, J. (2013) Conocimientos y actitudes sobre sexualidad en jóvenes es universitarios. Revista Electrónica de Psicología Iztacala, 16, 258-268. http://www.revistas.unam.mx/index.php/repi/article/download/36537/33080

[27] Instituto Mexicano de la Juventud (INJUVE) (2010) Encuesta Nacional de Juventud. Resultados generales Yucatán. Gobierno de México.

https://www.imjuventud.gob.mx/imgs/uploads/Presentacion_ENJ_2010_Dr_Tuiran =V4am.pdf

[28] Lama-González, E., Godoy-Montañez, C., Aguilar-Ayala, F., Rejón-Peraza, M. and Gutiérrez-Solís, A. (2008) Nivel de conocimiento de los estudiantes con respecto a 
la transmisión del VPH. Revista Odontológica Latinoamericana, No. 1, 5-8.

[29] American Psychiatric Association (APA) (2002) Manual Diagnóstico y Estadístico de los Trastornos Mentales DSM-IV-TR. Masson, Barcelona.

[30] Cajiao, L. (2007) Conductas parafílicas. http://correo.puj.edu.co/proyectosintesis/Hipervinculos/Sexualidad/Se00205a.htm

[31] Weeks, J. (2002) Héroes caídos? Todo sobre los hombres. In: Cortés, J.M., Ed., Héroes caídos: Masculinidad y representación, Espai D’Art Contemporani de Castello, Valencia, 132-195.

[32] Romi, J.C. (2004) Nomenclatura de las manifestaciones sexuales. Alcmeon, 11, No. 2.

[33] Cedillo Garrido, C.M. (2013) Percepción y conductas hacia el sexo oral en estudiantes universitarios. Congreso Virtual Internacional sobre Psicología (CIPS2013) México. http://salutsexual.sidastudi.org/es/registro/ff80818150d7e8570151386de04b02a3

[34] Valdez Montero, C., Benavides Torres, R.A., González y González, V., Onofre Rodríguez, D.J. and Castillo Arcos, L. (2015) Internet y conducta sexual de riesgo para VIH/SIDA en jóvenes. Enfermería Global, 14, 151-159. https://doi.org/10.6018/eglobal.14.2.196561

[35] Whisman, V. (1996) Queer by choice: Lesbians, gay men, and the politics of identity. Routledge, New York.

[36] Ubillos, S., Páez, D. and González, J. (2000) Culture and Sexual Behavior. Psicothema, 12, 70-82.

[37] Yost, M.R. and Zurbriggen, E.L. (2006) Gender Differences in the Enactment of Socio-Sexuality: An Examination of Implicit Social Motives, Sexual Fantasies, Coercive Sexual Attitudes, and Aggressive Sexual Behavior. Journal of Sex Research, 2, 163-173. https://doi.org/10.1080/00224490609552311

[38] Cañizo-Gómez, E. and Salinas-Quiroz, F. (2010) Conductas sexuales alternas y permisividad en jóvenes universitarios. Enseñanza e Investigación en Psicología, 15, 285-309. https://www.redalyc.org/articulo.oa?id=29215980004 


\section{Appendix 1}

A survey instrument for evaluating psychological variables and risky sexual behavior

Reference: Piña López JA, Robles Montijo S, Rivera Icedo BM. Instrumento para la evaluación de variables psicológicas y comportamientos sexuales de riesgo en jóvenes de dos centros universitarios de México. Rev Panam Salud Publica. 2007; 22(5): 295-303.

\section{BACKGROUND AND SEXUAL BEHAVIORS}

1. Have you had sex with penetration?
(1)
(1.1) Yes (go to question 2 and continue answering according to the indications)
(1.2) No (go directly to question 20)

2. If you have had sex with penetration, how old were you?

(2.1) (Specify the age in years)

\section{(RESPOND TO THE FOUR OPTIONS)}

1. VERY DETERMINANT 2. MORE OR LESS DETERMINATE

3. LITTLE DETERMINANT 4. NOT AT ALL DETERMINANT

\begin{tabular}{|c|c|c|c|c|c|}
\hline No. & QUESTIONS & 1 & 2 & 3 & 4 \\
\hline 3. & \multicolumn{5}{|c|}{ Of the reasons indicated below, in retrospect, how decisive Was each one of them so that you started your active sex life? } \\
\hline 3.1 & Because the opportunity to have relationships was presented & & & & \\
\hline 3.2 & Because I was interested in experiencing and knowing what I felt & & & & \\
\hline 3.4 & Because there was an important emotional relationship with the other person & & & & \\
\hline 4. & \multicolumn{5}{|c|}{ Of some biological states listed below, In retrospect, how much did each of them influence you to have started your active sex life? } \\
\hline 4.1 & I was physically/excited & & & & \\
\hline 4.3 & I was under the influence of a drug & & & & \\
\hline 5. & \multicolumn{5}{|c|}{$\begin{array}{l}\text { Of the social situations listed below, in retrospect, how much did each of them facilitate things so that Have you had your first sexual } \\
\text { relationship with penetration? }\end{array}$} \\
\hline 5.1 & alone with the couple in a private place & & & & \\
\hline 5.2 & Meeting alone with the couple at a party or meeting & & & & \\
\hline 5.3 & in a place for adult shows & & & & \\
\hline
\end{tabular}

6. When you had your first sexual relationship with penetration, did you use a condom?

(6.1) Yes (go to question 7, do not answer 8 and then go to 9)

(6.2) No (go to question 8 and continue with 9)

1. VERY DETERMINANT 2. MORE OR LESS DETERMINATE

3. LITTLE DETERMINANT 4. NOT AT ALL DETERMINANT 


\begin{tabular}{|c|c|c|c|c|c|}
\hline No. & QUESTIONS & 1 & 2 & 3 & 4 \\
\hline 7. & \multicolumn{5}{|c|}{$\begin{array}{l}\text { If you used a condom during your first sexual intercourse with penetration, the reasons indicated below, could you tell us how decisive } \\
\text { each one was to have used it? }\end{array}$} \\
\hline 7.1 & To avoid pregnancy & & & & \\
\hline 7.2 & To avoid a sexually transmitted infection & & & & \\
\hline 7.3 & Because I demanded it from my partner & & & & \\
\hline 7.4 & Because my partner demanded it from me & & & & \\
\hline 8. & \multicolumn{5}{|c|}{$\begin{array}{l}\text { If you did not use a condom during your first sexual intercourse with penetration, of the reasons indicated below, Could you tell us } \\
\text { how decisive each one of them was for not having used it? }\end{array}$} \\
\hline 8.1 & Because my partner did not want to use it & & & & \\
\hline 8.2 & Because I did not want to use it & & & & \\
\hline 8.3 & Because it reduces sensitivity and pleasure to the relationship & & & & \\
\hline 8.4 & Because at that time I did not bring one with me & & & & \\
\hline
\end{tabular}

9. Now, throughout your active sex life, how often have you used condoms?

\begin{tabular}{|l|}
\hline \\
\hline \\
\hline \\
\hline \\
\hline \\
\hline \\
(9.2) Most of the time (go to question 11 and then continue with 12) \\
(9.4) Never (go to question 11 and then continue with 12)
\end{tabular}

1.VERY DETERMINANT 2. MORE OR LESS DETERMINATE

3. LITTLE DETERMINANT 4. NOT AT ALL DETERMINANT

\begin{tabular}{|c|c|c|c|c|c|}
\hline No. & QUESTIONS & 1 & 2 & 3 & 4 \\
\hline 10. & \multicolumn{5}{|c|}{$\begin{array}{l}\text { If you have always used condoms throughout your sex life, in retrospect, of the reasons indicated below, could you tell us how decisive } \\
\text { each one has been for you to always use a condom? }\end{array}$} \\
\hline 10.1 & To avoid pregnancy & & & & \\
\hline 10.2 & To avoid a sexually transmitted infection & & & & \\
\hline 10.3 & Because I demanded it from my partner & & & & \\
\hline 10.4 & Because my partner demanded it from me & & & & \\
\hline 11. & \multicolumn{5}{|c|}{$\begin{array}{l}\text { If you have not used condoms throughout your active sex life, that is, if you have you used most of the time, very rarely or never, in } \\
\text { retrospect, of the reasons given below, could you tell us how decisive each one was so that you have not always used a condom? }\end{array}$} \\
\hline 11.1 & Because I did not want to use it & & & & \\
\hline 11.2 & Because my partner did not want to use it & & & & \\
\hline 11.3 & Because it reduces sensitivity and pleasure to the relationship & & & & \\
\hline 11.4 & Because despite knowing how to use it, at that time I did not bring a partner & & & & \\
\hline
\end{tabular}

12. Since you started your active sex life and until today, how many sexual partners have you had?

\begin{tabular}{|l|}
\hline \\
\hline$\square$ \\
\hline$\square$ \\
\hline \\
\hline \\
\hline \\
(12.2) Between two and four partners (continue responding according to the indications) \\
(12.4) Eight or more partners (continue responding according to the indications)
\end{tabular}


13. Have you had relationships with penetration with occasional partners, that is, with people you didn't know or knew little about?
$\square$
(13.1) Yes (continue with the 14 and then according to the indications)
(13.2) No (YOU FINISHED THANK YOU)

\section{VERY DETERMINANT 2. MORE OR LESS DETERMINATE \\ 3. LITTLE DETERMINANT 4. NOT AT ALL DETERMINANT}

\begin{tabular}{|c|c|c|c|c|c|}
\hline NO & QUESTIONS & 1 & 2 & 3 & 4 \\
\hline 14. & \multicolumn{5}{|c|}{$\begin{array}{l}\text { Of the reasons given below, in retrospect, how decisive was each to have had sexual relations with occasional partners, that is, with } \\
\text { couples you knew little or did not know? }\end{array}$} \\
\hline 14.1 & Because the opportunity to have sex was presented & & & & \\
\hline 14.2 & Because I wanted to experience and know what it felt like & & & & \\
\hline 14.3 & Because I was physically attracted to other people & & & & \\
\hline 15. & \multicolumn{5}{|c|}{ From some biological states listed below, how much did each one influence having sex with partners? occasional? } \\
\hline 15.1 & I was excited / or physically & & & & \\
\hline 15.2 & I was under the influence of alcohol & & & & \\
\hline 15.3 & I was under the influence of a drug & & & & \\
\hline 16. & \multicolumn{5}{|c|}{ Of the social situations listed below, how much do you consider facilitated each of them to have sex with casual partner? } \\
\hline 16.1 & Finding myself alone with the partner in a private place & & & & \\
\hline 16.2 & Finding myself alone with the partner at a party or meeting & & & & \\
\hline 16.3 & Finding myself in a place of shows for adults & & & & \\
\hline
\end{tabular}

17. Since you mention that you have had sexual relations with occasional partners, that is, With couples you knew little or just didn't know, could you tell us how often you used condoms with these types of couples?

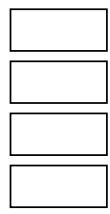

(17.1) Always (go to question 18, not answer 19)

(17.2) Most of the time (go to question 19)

(17.3) Very rarely (go to question 19)

(17.4) Never (go to question 19)

\section{VERY DETERMINANT 2. MORE OR LESS DETERMINATE}

\section{LITTLE DETERMINANT 4. NOT AT ALL DETERMINANT}

\begin{tabular}{|c|l|c|c|c|}
\hline No. & \multicolumn{1}{|c|}{ QUESTIONS } & \multicolumn{1}{|c|}{1} & \multicolumn{1}{|c|}{$\mathbf{2}$} & $\mathbf{3}$ \\
\hline 18. & $\begin{array}{l}\text { Of the reasons indicated below, in retrospect, how decisive was each one to always use a condom every time you had sex with casual } \\
\text { partners? }\end{array}$ & & & \\
\hline 18.1 & To avoid pregnancy & & & \\
\hline 18.2 & To avoid a sexually transmitted infection & & & \\
\hline 18.3 & Because in each case I demanded it from my partners & & & \\
\hline 18.4 & Because in each case my partners demanded it from me & & \\
\hline 19 & $\begin{array}{l}\text { Of the reasons below, could you tell us how decisive Was each one not to always use a condom when you had sex with casual partners, } \\
\text { that is, couples you knew little or did not know? }\end{array}$ \\
\hline
\end{tabular}




\section{Continued}

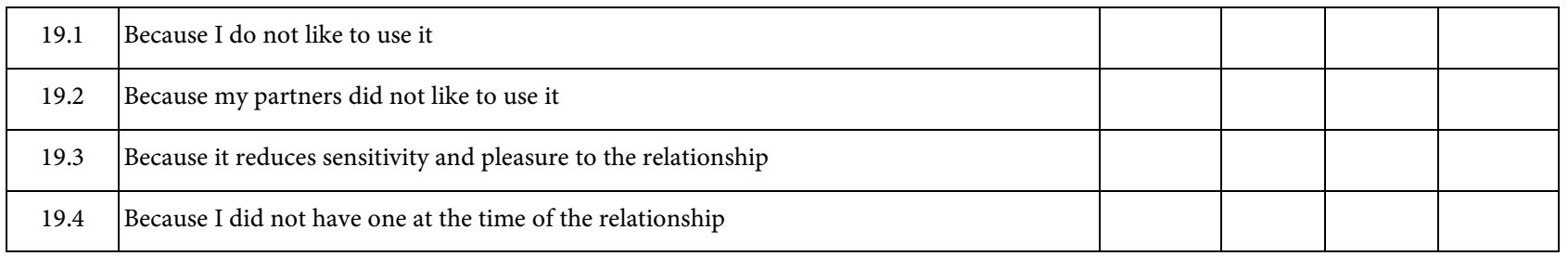

\section{SECTION FOR PEOPLE WHO NOT HAVE HAD SEXUAL RELATIONS WITH PENETRATION}

Although you have not had sex with penetration, it is important that you answer the following questions.

\begin{tabular}{|c|l|c|c|c|c|}
\hline No. & \multicolumn{1}{|c|}{ QUESTIONS } & 1 & $\mathbf{2}$ & $\mathbf{3}$ & $\mathbf{4}$ \\
\hline 20. & How decisive has each of the reasons mentioned below been for you so that you have not had relationships with penetration? \\
\hline 20.1 & Because I want to avoid a sexually transmitted infection & & & & \\
\hline 20.2 & Because I want to have relationships with anyone in love & & & & \\
\hline 20.3 & Because I want to avoid a pregnancy & & & & \\
\hline 20.4 & Because I want to put into practice the way I have been educated & & & & \\
\hline
\end{tabular}

21. Have you had sex of a kind oral?
$\square$
(21.1) Yes (go to question 22 and keep answering)
(21.2) No (go to question 25)

22. If you had oral relations, what person was it?

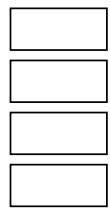

(22.1) My girlfriend

(22.2) From a friend

(22.3) From casual partner I didn't know much

(22.4) From sex workers

23. When you have had oral relationships, have you used a condom?

(23.1) Yes (go to question 12)

(23.2) No (go to question 13)

1. VERY DETERMINANT 2. MORE OR LESS DETERMINATE

\section{LITTLE DETERMINANT 4. NOT AT ALL DETERMINANT}

\begin{tabular}{|c|c|c|c|c|c|}
\hline No. & QUESTIONS & 1 & 2 & 3 & 4 \\
\hline 24. & \multicolumn{5}{|c|}{ How decisive has each of the reasons mentioned below been for you to use a condom when you have had oral relationships? } \\
\hline 24.1 & Because I want to avoid a sexually transmitted infection & & & & \\
\hline 24.2 & Because I have wanted to use it & & & & \\
\hline 24.3 & Because the couple has asked me to use it & & & & \\
\hline 24.4 & Because I do not know the sexual background of the couple & & & & \\
\hline
\end{tabular}


IMAGINE NOW THAT YOU ARE IN A SITUATION WHERE THERE IS A HIGH CHANCE OF RELATIONSHIPS SEXUALS WITH PENETRATION HOW LIKELY WOULD IT BE?

25. Ask the couple about their sexual background

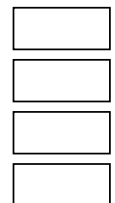

(25.1) Not at all likely

(25.2) More or less likely

(25.3) Very likely

(25.4) Fairly likely

26. Reject the proposal to have sex

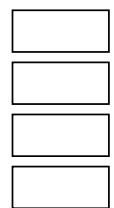

(26.1) Not at all likely

(26.2) More or less likely

(26.3) Very likely

(26.4) Quite likely

27. You reject the proposal to even touch the sensitive areas of your body (breasts, and clitoris in the case of women and penis or testicles in the case of men.

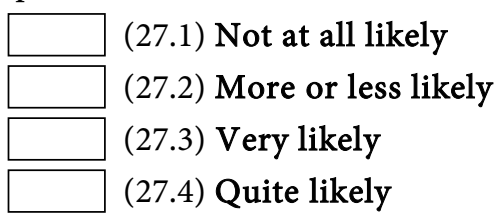

28. Ask the couple to use a condom

\begin{tabular}{|l|}
\hline \\
\hline$\square$ \\
\hline$\square$ \\
\hline$\square$
\end{tabular}

(28.1) Not at all likely

(28.2) More or less likely

(28.3) Very much very likely

(28.4) Quite likely

¡THANK YOU FOR YOUR VALUABLE COLLABORATION!

Translate by Ávila-Escalante, ML 